\title{
Research on the Payment Management of Cross-border Electricity
}

\section{Business}

\author{
Qiang $\mathrm{Ma}^{1}$ \\ ${ }^{1}$ Business School, Xi'an International University, Xi'an, Shaanxi, 710077
}

\section{KEYWORDS: Payment Management; Cross-border Electricity Business; Market System}

\begin{abstract}
With the development of international trade and e-commerce, cross-border e-commerce in recent years has also been rapid development. Traditional offline payment due to the long payment period, cumbersome problems spawned a variety of cross-border e-commerce settlement. A variety of online payment methods and information dissemination, online communication, integration Logistics Services achieved success today, eBay, Amazon, DHgate wholesale and retail trade and other online platforms.
\end{abstract}

\section{Introduction}

Our e-commerce and e-business payments business will become a new way to make money. Some foreign researchers forecast on China's cross-border e-commerce industry show that Chinese e-commerce industry will pay the value of the transaction in the world in the mid-2000s to reach about \$ 2 trillion, this value will be higher than the early 21st century electronic the amount of business and payment services, development of e-commerce industry is very large as well as all kinds of hidden profit margins will inevitably lead to a variety of domestic and foreign economic agents a universal concern. According to statistical analysis of data related to the staff of e-commerce, from the early 20th century in the field of electronic commerce and payment services distributed in the traditional areas has gradually narrowing, from the mid-20th century, when China's electronic business in aviation, telecommunications and other industries occupies areas between various sectors has been raised from $73 \%$ decreased $68 \%$ in the middle of the 21 st century, the researchers expect the proportion in this period will be reduced to $50 \%$ during the same period, as China's e-commerce industry in education, the use of public utilities costs, the insurance industry, stocks and mutual funds and other financial products also began to market in a timely manner of the layout of e-commerce payment services on the domestic market gradually began to stabilize development situation. Under domestic and cross-border e-commerce market is very competitive state, from the condition of the rapid development of e-commerce research and analysis on the opportunities of e-commerce market experience, our e-commerce market to go cross-border e-commerce market is undoubtedly Electronics commerce and payment services in a competitive international primary anchor. Liquidity of large cross-border e-commerce and payment services, these cross-border e-commerce will bring a lot of options in terms of capital flows, the basic development of cross-border payment services from our current consideration of cross-border e on the settlement payment business it is mainly used by banking institutions to buy some funds and then transferred out of the way or be a settlement of cross-border e-commerce revenues by way of income between these two approaches contain third party That institution payment institutions, these institutions in our cross-border e-commerce activities play a very important role. 


\section{Cross-Border Business Development Status}

With cross-border e-commerce and domestic non-financial institutions to pay the rapid development of business, some of the larger, more mature payment mechanism, expand cross-border payment services demand gradually strong, repeatedly expressed to set up cross-border foreign exchange SAFE the urgent desire of the Internet payment services. In 2009, the State Administration of Foreign Exchange approved the Zhejiang Alipay and TenPay Shenzhen opened offshore acquiring business, but the external card payment business has not been liberalized. But in fact, the way individual payment institutions to set up branches overseas through disguise undertaken wild card payments. In 2012, China accounted for the largest cross-border third-party payment market share of Alipay, cross-border payments totaling approximately $\$ 900$ million, accounting for only $5 \%$ of total cross-border e-commerce transactions, and tens of billions of dollars each year the size of cross-border third party payment market is mainly paid for by the United States and other foreign monopoly PayPal. A large number of cross-border e-commerce businesses to open accounts abroad to receive payment, and flows back through the territory of the spin-off personal foreign exchange and other means. Meanwhile, the offshore companies pay fees for Chinese foreign trade enterprises is not only high, and management demanding, in the event of a dispute generally favoring foreign cardholders funds frequently frozen Chinese enterprises for half a year. Therefore, the support of its own to pay the company to expand cross-border business, for the promotion of cross-border e-commerce and third-party payment market's healthy development of great significance.

Cross-border e-commerce and third-party payment management involves multiple departments industry and commerce, customs, tax, business and foreign exchange management. Currently, cross-border e-commerce lacks of third-party payment systems industry regulations. E-commerce and third-party payment categories regulations and guidance for industry and commerce, business and other departments enacted, only a clear attitude to encourage the development of electronic commerce and third-party payment industry is not yet clear cross-border e-commerce and third-party payment industry regulatory requirements. "Non-financial institution payment service management approach" issued by the People's Bank, the main specification is paid within the agency business and management did not involve cross-border business. Therefore, the current cross-border payment institutions to manage regulatory gaps still exist.

\section{E-Commerce and Payment Services on Management Problems}

The rapid development of cross-border e-commerce and payment services companies to bring great returns, but of cross-border e-commerce and payment services that improper use may give companies great economic losses in the management system, combined with our cross-border a series of electronic commerce and payment services in the management of the current environment, the presence, the author conducted a comprehensive analysis and research. These problems are mainly manifested as: My cross-border e-commerce and payment services lack the protection of government policy on the management aspect; of cross-border e-commerce and payment services appeared stagnant in the operation.

So far the government has not issued the relevant policies on the type of cross-border e-commerce activities were legal recognition, foreign currency transactions related to cross-border e-commerce and payment services related to the management of the home is difficult to fully grasp. Our cross-border e-commerce and payment services activity occurred in virtual situations, directly to foreign exchange regulators cross-border e-commerce and payment services activities of real 
legitimacy and funding is difficult to examine, cross-border payments after the transaction by means of a substantial completion of activities on the platform, trading capital accounting is usually $10 \mathrm{~d}$ or so, so in the trading activities of foreign income is difficult to achieve both tranches.

\section{Cross-Border E-Commerce and Third-Party Payment Services}

Cross-border e-commerce and third-party payment service not only for the import and export enterprises to provide a convenient way to pay for online transactions and, through a third party payment institutions and credit intermediary function and reduce the domestic enterprises to enter new markets, credit risk, and its development will greatly to promote trade facilitation process in China. However, in our country to carry out cross-border flow of foreign exchange funds under stricter supervision background, cross-border payments from a third party to break through various aspects of the existing regulatory system, resulting in new venture capital flows. In this regard, foreign exchange management departments should actively respond to efforts to balance the dual aspects of demand and strictly control risks and to promote the development, in full recognition of the positive significance of cross-border e-commerce and the development of third-party payment industry, while vigorously do research, identify risk areas, develop targeted regulatory measures, feasibility, operability, and promote China's non-bank payment steady and orderly development of the industry.

In order to better control risk, steadily promote the development of payment institutions, would be a conditionally and gradually promote the rational choice. First of all, may be allowed to have a certain scale, cross-border Internet payment service pilot forex risk control measures more complete payment institution to provide agents to foreign exchange and foreign exchange services for cross-border Internet transactions with realistic backgrounds. SAFE will have to do the first business counseling, guide enterprises to establish and improve the internal control system within the framework of the management of foreign exchange, but also pay attention to constantly adjust their business to carry out in accordance with regulatory measures, the summary regulatory experience, comprehensive payment industry for the future open to lay the foundation. Secondly, the regulatory SAFE payment institutions cross-border payments should be based on the basic principles of business regulation, depending on the different services involved in the implementation of funding cross-border flow pattern of targeted regulation, electronic payment channels gradually liberalized by the Internet, by the small business trade in goods and services clearly part of the transaction price of trade, gradually expanded to large price fluctuations or trade in goods and services, and to develop a formal management approach to be fully standardized and promotion.

Cross-border e-commerce is just the traditional international trade electronic process, the main contents of the transaction remains goods and services. Thus, mutatis mutandis, the traditional management principles of international trade, cross-border e-commerce will be included in foreign exchange balance current foreign exchange management areas, according to authenticity, convenience and balance management principles to manage and ensure legal compliance of the transaction. At the operational level, the development of specific foreign exchange business regulations, payment institutions to further clarify the scope and qualifications to handle the business, as well as the division of responsibilities and cooperation between banks. First, a clear mechanism for the payment of management is requiremented. Will be regarded as payment institutions designated foreign exchange bank management, specifically responsible for the

authenticity of its transactions, and around this principle, the establishment of customer identification system, the transaction record-keeping system, establish a sound risk control system 
and internal supervision system. Second, a clear regulatory requirement for cooperative banks. Cooperative bank shall pay the agency to pay part of the collection of audit, on behalf of the transaction subject to cross-border electronic payment transactions transaction-reporting. SAFE is to strengthen the banks and payment institutions non-spot verification and on-site inspection. Meanwhile, referring to goods and services trade foreign exchange management mode, the full collection orders payment institutions, logistics data and balance of payments data reporting case by case basis, according to the project are included in the transaction of foreign exchange monitoring system of trade in goods and trade in services business off-site supervision of foreign exchange management system, verification and implementation of the total off-site supervision based on this.

\section{Conclusion}

Cross-border e-commerce and third-party payment management involves multiple departments industry and commerce, customs, tax, business and foreign exchange management. SAFE foreign exchange at the time of cross-border capital flows to develop regulatory measures necessary to give full consideration to the actual work of China's foreign exchange management should actively coordinate with relevant departments, continue to promote the whole cross-border e-commerce and third-party payment industry establish and improve the supervision system of orientation. Specific operations can be considered with related departments to develop credible standards, the establishment of cross-border e-commerce credit monitoring public service platform. Business initiative to orders, payment and logistics data into the platform, the platform for their online transactions certification, the order flow, capital flow and logistics "third one" cross-check to ensure the authenticity and legality of the transaction. Included credible system of business, you can enjoy convenient services customs, industry and commerce, business, taxation and foreign exchange management departments to provide.

\section{Reference:}

[1] Lue Cassivi, MichaeI Wybo, Pierre-Majorique Leger and Pierre Hadaya The Level of International Business and its Association with Different Internet E-commerce Practices [J]. IEEE Computer Society, 2010,11: 222-225.

[2] Lee. W. Meknight, Joseh. P. Baley. Product Difference and Intraindustry Trade [J]. Journal of Economics, 2007,05: P313-323.

[3] Ali Ghorbani, Mohammad Bakhtazmay Bonab Globalization and the Role of E-commercein Its Expansion [J]. Journal of Basic and Apply Scientific Research, 2013,3:.. 78-82.

[4] Abbas Asosheh, Hadi Shahidi-Nejad and Hourieh Khodkari. A Model of a Localized Cross-Border E-commerce [J]. Scientific Research 2012,4:.. 136-145.

[5] Jennifer Gibbs, Kenneth L. Kraemer and, Jason Dedrick .Enviroment and Policy Factor Shaping Global E-commerce Diffusion: A Cross-County Comparison [J]. The Information Society, 2006: 19: 5-1. 